\title{
MEKANISME AKSI $\alpha$-MANGOSTIN DARI GARCINIA TETRANDA PIERRE TERHADAP P.FALCIPARUM SECARA IN VITRO
}

\author{
Hadi Kuncoro ${ }^{1)}$, Aty Widyawaruyanti ${ }^{2)}$, Taslim Ersam ${ }^{3)}$ \\ Kelompok Bidang Ilmu Biologi Farmasi, Fakultas Farmasi Universitas, Samarinda \\ e-mail : kuncoro_hadi82@yahoo.com ${ }^{1)}$ \\ Departemen Farmakognosi Dan Fitokimia, Fakultas Farmasi, Universitas Airlangga, \\ Surabaya ${ }^{2)}$ \\ Progrman Pasca Sarjana Kimia Institut Teknologi Surabaya, Surabaya ${ }^{3)}$
}

\begin{abstract}
Development stage of parasite resistance assay and the Globin accumulation using SDSPAGE Method has been done to parasite P. falciparum by giving $\alpha$-mangostin from $G$. tetranda. $\alpha$-Mangostin cause delays in the development stage of the parasite $P$. falciparum from stage schizont to stage trofozoit and cause parasite death after 48 hour. Swelling of the parasite of abnormal parasite food vacuole occurred after administration of $\alpha$-Mangostin show from the results of SDS-PAGE.
\end{abstract}

Key word : $\alpha$-Mangostin, G. tetranda, P. falciparum, globin accumulation

\begin{abstract}
ABSTRAK
Telah dilakukan pengujian hambatan perkembangan stadium parasit dan akumulasi globin menggunakan metode SDS- PAGE terhadap P. falciparum dengan pemberian $\alpha$-Mangostin dari G. tetranda. Diketahui $\alpha$-Mangostin menyebabkan penundaan perkembangan parasit $P$. falciparum dari stadium trofozoit menjadi stadium skizon dan menyebabkan parasit mati setelah jam ke 48. Pembengkakan vakuola makanan parasit yang abnormal terjadi setelah pemberian $\alpha$-Mangostin terlihat dari hasil SDS-PAGE.
\end{abstract}

Kata Kunci : $\alpha$-Mangostin, G. tetranda, P. falciparum, , akumulasi globin

\section{PENDAHULUAN}

Garcinia merupakan salah satu genus yang tersebar luas diseluruh dunia, terutama didaratan rendah hutan hujan tropis Asia tenggara maupun afrika bagian barat. Tanaman yang merupakan keluarga dari Guttiferae ini digunakan secara umum sebagai obat tradisional dan diketahui kaya akan metabolit sekunder diantaranya biflavonoid, santon, dan isoprenil benzofenon. Senyawa yang banyak ditemukan dalam spesies Garcinia umumnya memberikan bioaktifitas, seperti antioksidan, sitotoksik, antibakteri, bahkan sebagai antimalaria. Salah satu spesies Garcinia yang belum banyak diteliti adalah Garcinia tetranda Pierre (wadung). Spesies ini banyak ditemui di daerah Indonesia Timur an merupakan koleksi Taman Nasional Meru Betiri, Jember.

Berdasarkan hasil penelitian kelompok kimia tumbuhan ITS, G. tetranda Pierre dilaporkan mengandung senyawa santon, khususnya santon terprenilasi mulai dari 
monoprenilasi sampai triprenilasi. Bagianbagian tertentu dalam satu tumbuhan berpeluang menghasilkan senyawa yang sama atau berbeda. Jenis santon terprenilasi seperti $\alpha$-mangostin yang diisolasi dari kulit akar tanaman ini juga ditemukan dalam tumbuhan Garcinia mangostana dan dilaporkan aktivitasnya sebagai antimalaria [1].

Berdasarkan laporan penelitian terdahulu terhadap pengujian penghambatan pertumbuhan parasit Plasmodium falciparum secara in vitro terhadap delapan senyawa santon yang diisolasi dari tumbuhan Garcinia tetranda Pierre (Wadung), diketahui bahwa $\alpha$-mangostin memiliki nilai $\mathbf{I C}_{\mathbf{5 0}} \mathbf{0 , 5 . 1 0 ^ { - 3 }} \boldsymbol{\mu} \mathbf{M}$, nilai ini lebih kecil dibandingkan standar kloroquin difosfat yang memiliki nilai $\mathbf{I C}_{\mathbf{5 0}}=\mathbf{3} \cdot \mathbf{1 0}^{-\mathbf{3}}$ $\boldsymbol{\mu} \mathbf{M}$, hal ini menunjukkan bahwa kedua senyawa tersebut sangat poten untuk ditindak lanjuti menjadi obat antimalaria baru [2].

Senyawa aktif antimalaria bersifat sebagai inhibitor pada proses degradasi hemoglobin, maka inhibitor akan menghambat proses yang terkait dengan pembentukan asam amino sebagai kebutuhan esensial bagi pertumbuhan parasit malaria. Begitu juga hambatan proses detoksifikasi heme, menyebabkan terjadinya penumpukan heme bebas pada vakuola makanan dan akan bersifat toksik sehingga melisis membran, mengakibatkan hemolisis dan menghambat aktivitas beberapa enzim. Hal ini berpengaruh pada metabolisme parasit dan menyebabkan kematian parasit [3].

Pada Kesempatan ini akan dibahas pengujian hambatan perkembangan stadium dari $P$. falciparum dan akumulasi globin menggunakan metode SDS PAGE akibat pemberian $\alpha$-Mangostin.

\section{METODE}

\section{Sampel dan Bahan}

Sampel penelitian yaitu senyawa aktif $\alpha$ mangostin yang diisolasi dari kulit batang wadung (Garcinia tetranda Pierre) berasal dari Taman Nasional Meru Betiri, Jember, Provinsi Jawa Timur. Parasit malaria $P$. falciparum, yaitu parasit malaria $P$. falciparum strain 3D7 berasal dari Institute Biologi Molekuler Eijkman, Jakarta. Bahan yang digunakan untuk pembiakan parasit $\mathrm{NaCl}$ (Merck), RPMI 1640, HEPES buffer, $\mathrm{NaHCO}_{3}$, hypoxanthine (Merck), Dsorbitol (Sigma), gentamisin sulfat (Sigma), serum dan sel darah manusia, aquadest steril for irrigation (Otsuka), larutan pewarna giemsa, minyak imersi. Bahan untuk Pengujian Perkembangan Stadium dan Akumulasi Globin Parasit Malaria $P$. falciparum adalah Sorbitol (Merck), DMSO (dimetilsulfoksida) (Merck), saponin (Sigma), PBS (Phosphate Buffered Saline), ammonium per sulfat, TEMED, aquadest steril, akrilamid, bisakrilamid, tris, sodium dodesil sulfat (SDS), asam klorida ( $\mathrm{HCl})$ (Merck), glisin, gliserol (Merck), $\quad \beta$ mercaptoetanol, bromfenol blue, pewarna perak nitrat $\left(\mathrm{AgNO}_{3}\right)$, metanol absolut, asam asetat glasial, glutaraldehid, Bovine Serum Albumin (BSA) (Sigma), reagen Bradford (Biorad).

\section{Instrumen}

Instrumen yang digunakan adalah Blue tip, yellow tip, culture tube, autoclaf, oven, botol laborat (Scott-Duran), tabung sentrifuse bertutup 15 dan $50 \mathrm{~mL}$ (Falcon), pipet mikro (Socorex dan Ependorf), pinset, lampu spiritus, Laminar Air Flow (LAF/clean bench), mikroskop (Olympus $\mathrm{CH}-20)$, gelas obyek, lempeng mikro (microplate), petridish, seperangkat peralatan SDS-PAGE (Biorad), beaker glass, gelas ukur, vortex, penangas air, 
shaker (penggoyang otomatis), kertas saring, pinset, termometer, spuit mikro, box untuk pewarnaan, spektrofotometer, kuvet.

\section{Uji Hambatan stadium $P$. falciparum}

Parasit stadium cincin dengan $\pm 1 \%$ parasitemia yang telah disinkronisasi dikultur bersama bahan uji dan kontrol dengan menggunakan 24-well culture plates. Pada jam-jam tertentu (jam ke-0, 6, $12,24,48$ dan 72) eritrosit yang terinfeksi parasit diambil, dibuat hapusan tipis di atas gelas obyek, difiksasi dengan metanol, diwarnai dengan Giemsa dan difoto.

\section{Uji Akumulasi Globin dengan Metode SDS-PAGE}

Parasit pada stadium cincin dengan $\pm 5 \%$ parasitemia yang telah disinkronisasi, dikultur dengan menggunakan petridish bersama bahan uji dan kontrol dengan dosis seperti pada 4.7.4.1.1. Kontrol negatif yang digunakan pada metode SDS-PAGE ada 2 macam, yaitu parasit yang dikoleksi pada jam ke-0 (stadium cincin) dan parasit yang dikoleksi pada jam ke-24 (akan berkembang menjadi stadium skizon). Sedangkan kontrol positif E-64 dan zat uji diinkubasi bersama dengan parasit malaria selama 24 jam.

\section{PEMBAHASAN}

\section{Uji Hambatan Stadium}

Pengujian perkembangan stadium dan morfologi parasit di dalam penelitian ini dilakukan secara in-vitro terhadap kultur $P$. falciparum strain 3D7. Strain 3D7 ini adalah termasuk kelompok strain yang masih sensitif (susceptible) terhadap klorokuin [4]. Plasmodium diambil dari simpanan beku, dilakukan proses thawing dan kemudian baru dapat dibiakkan secara in vitro. Secara umum, siklus hidup $P$. falciparum di dalam biakkan kultur in vitro berkisar antara 46-48 jam. Stadium parasit malaria dimulai pada stadium cincin (mulai jam ke-0 sampai \pm jam ke-12). Pada jam ke-12 parasit telah berkembang menjadi stadium trofozoit dan kemudian berubah menjadi stadium skizon pada jam ke-24. Pada stadium skizon mulai terjadi proses pembelahan inti parasit. Masing-masing inti akan berkembang menjadi merozoitmerozoit, kemudian pecah dan menginvasi eritrosit baru. Proses ini berlangsung mulai dari jam ke-24 sampai \pm jam ke-48. Demikian proses ini berlangsung terusmenerus. Sedangkan pada jam ke-12, parasit pada kontrol negatif tampak terjadi perubahan dari stadium cincin menjadi stadium trofozoit dewasa. Pada perkembangannya menjadi trofozoit, parasit dapat dikatakan secara metabolik aktif karena pada stadium ini terjadi peningkatan yang besar terhadap pengambilan hemoglobin dari eritrosit hospes masuk ke dalam parasit dan diteruskan ke vakuola makanan untuk dicerna [3].

Hal yang menarik untuk diperhatikan terjadi pada jam ke-24. Pada kontrol negatif, parasit tumbuh normal menjadi stadium skizon. Hal ini membuktikan bahwa telah terjadi proses degradasi hemoglobin menjadi heme dan globin. Heme yang dihasilkan telah dipolimerisasi oleh parasit menjadi pigmen malaria yang berwarna kuning yaitu hemozoin. Sedangkan globin telah dipecah menjadi asam-asam amino dan ditranspor menuju sitoplasma untuk proses biosintesis protein parasit malaria. 
Sedangkan parasit yang diinkubasi dengan pemberian $\alpha$-mangostin tampak bahwa sebagian populasi parasit berada pada stadium trofozoit akan tetapi sebagian lainnya tetap berada dalam stadium cincin. Hal ini menunjukkan bahwa telah terjadi penghambatan perkembangan parasit dari stadium trofozoit menjadi stadium skizon. Seharusnya parasit yang tumbuh secara normal akan berkembang menjadi stadium skizon pada jam ke-24 seperti ditunjukkan pada kontrol negatif. Pada pengamatan jam ke-48 dan 72, stadium parasit pada kontrol negatif adalah stadium cincin, yang berarti pada 24 jam terakhir (jam ke-24 sampai jam ke-48 dan 72) telah terjadi pematangan skizon menjadi merozoit-merozoit. Hal ini ditunjukkan dengan persentase parasitemia pada kontrol negatif yang meningkat tajam dari $\pm 1 \%$ menjadi $\pm 3 \%$ pada jam ke $48 \pm$ $4 \%$ pada jam ke 72 , sedangkan parasit yang diinkubasi senyawa $\alpha$-mangostin terjadi penurunan persen parasitemia dan akhirnya mati pada jam ke 48. Ada dugaan bahwa enzim sistein protease juga ikut berperan dalam pemecahan sitoskeleton parasit sehingga merozoit-merozoit dapat keluar dan menginvasi eritrosit yang baru. Akan tetapi hal ini masih diperdebatkan dan masih dicari kemungkinan adanya enzim lain yang juga ikut berperan dalam pemecahan sitoskeleton parasit [5].

Tabel 1. Perkembangan stadium dan morfologi P. falciparum (strain 3D7) yang diinkubasi dengan kontrol negatif dan $\alpha$-mangostin pada 0, 6, 12, 24, 48 , dan 72 jam ; kemudian dibuat hapusan tipis, diwarnai dengan giemsa dan diamati menggunakan mikroskop cahaya (Olympus CH-20) dengan perbesaran $10 \times 100$

\begin{tabular}{|c|c|c|}
\hline Jam & Kontrol negatif & $\alpha$-mangostin \\
\hline 0 jam & $\begin{array}{l}\text { - Stadium cincin } \\
\text { - Morfologi normal }\end{array}$ & $\begin{array}{l}\text { - Stadium cincin } \\
\text { - Morfologi normal }\end{array}$ \\
\hline $6 \mathrm{jam}$ & $\begin{array}{l}\text { - Stadium cincin } \\
\text { - Morfologi normal } \\
\text { - Trofozoit }\end{array}$ & $\begin{array}{l}\text { - Stadium cincin } \\
\text { - Morfologi normal }\end{array}$ \\
\hline 12 jam & $\begin{array}{l}\text { - Stadium trofozoit dewasa } \\
\text { - Normal }\end{array}$ & $\begin{array}{l}\text { - Stadium trofozoit muda } \\
\text { - Morfologi normal }\end{array}$ \\
\hline 24 jam & $\begin{array}{l}\text { - Stadium skizon } \\
\text { - Morfologi normal }\end{array}$ & $\begin{array}{l}\text { - Stadium cincin dan trofozoit } \\
\text { - Penebalan sitoplasma } \\
\text { - Morfologi normal } \\
\text { - Hemozoin berwarna kuning }\end{array}$ \\
\hline 48 jam & $\begin{array}{l}\text { - Stadium Ring } \\
\text { - Morfologi normal }\end{array}$ & - Parasit mati dan masih berada dalam eritrosit \\
\hline 72 jam & $\begin{array}{l}\text { - Stadium Ring } \\
\text { - Morfologi normal }\end{array}$ & - Tidak terlihat adanya parasit \\
\hline
\end{tabular}




\section{Akumulasi Globin Menggunakan SDS PAGE}

Hasil SDS-PAGE terhadap akumulasi globin dapat ditunjukkan dengan adanya pita (band) yang berwarna hitam pada posisi $16 \mathrm{kDa}$ [6]. Selain itu posisi pita globin juga dapat ditunjukkan dengan menggunakan hemoglobin standar (Sigma) (gambar 1, line 8) dan hemoglobin dari eritrosit yang digunakan untuk kultur parasit (gambar 1, line 2). Pada jam ke-0 (kontrol negatif $\mathrm{D}_{0}$ ) merepresentasikan awal mulainya inkubasi pada stadium cincin (gambar 1, line 7). Pada stadium cincin, proses pengambilan hemoglobin dari sitosol eritrosit masuk ke dalam parasit mulai terjadi [3]. Akan tetapi hemoglobin masih berada di sitosol parasit karena pada stadium cincin belum terbentuk vakuola makanan.Sedangkan parasit yang diberi zat uji $(\alpha$-mangostin ) terdapat pita globin. Hal ini menunjukkan adanya globin di dalam parasit malaria, hal ini sesuai dengan pengujian hambatan perkembangan stadium dimana parasit mengalami penundaan pada stadium trofozit yang berarti masih terjadi akumulasi globin di dalam vakuola makanan parasit malaria. Pembengkakan yang abnormal pada vakuola makanan parasit malaria dikatakan merupakan parameter yang spesifik terhadap penghambatan enzim sistein protease yang berkorelasi dengan penghambatan proses hidrolisis globin [7].

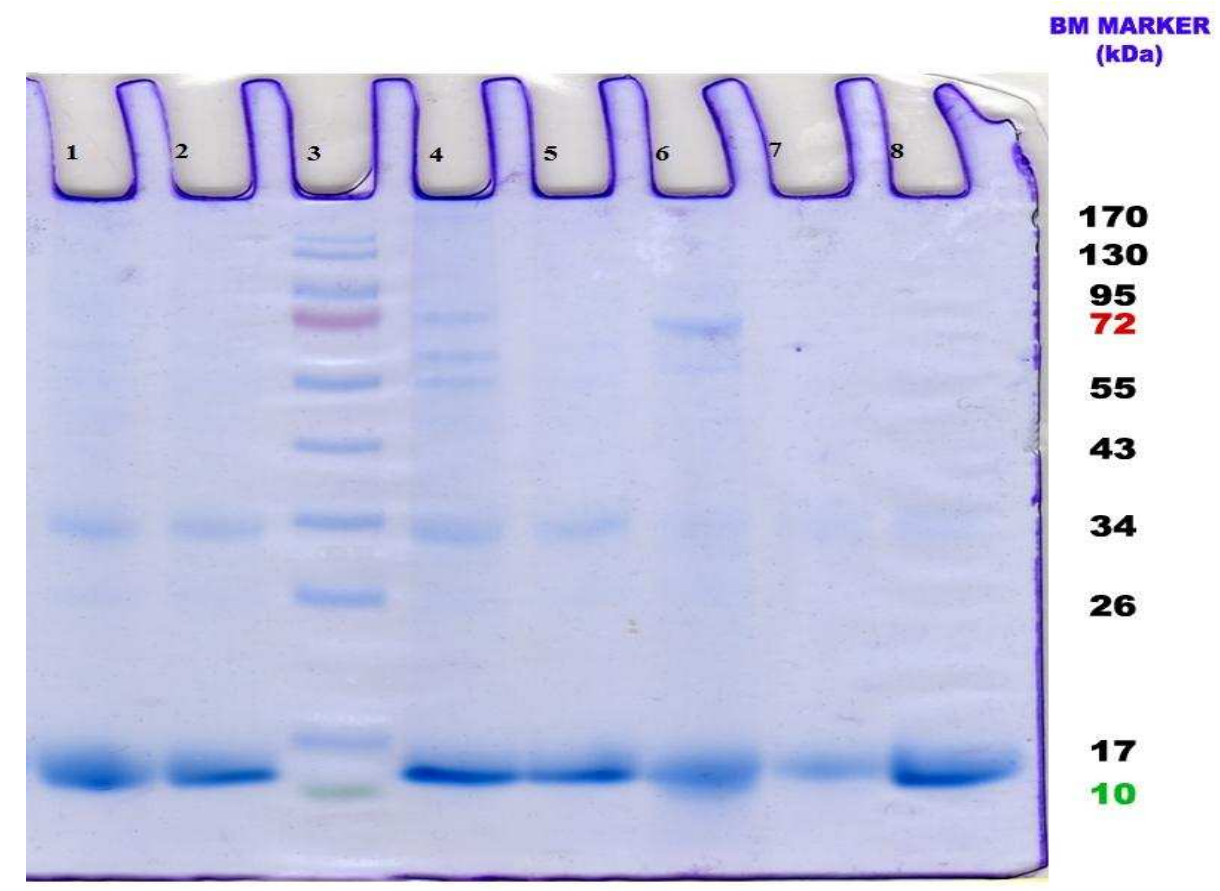

Gambar 1. Akumulasi globin pada gel hasil elektroforesis dari parasit malaria P. falciparum (strain 3D7) yang diinkubasi dengan $\alpha$-mangostin (line 4), kontrol positif E-64 (line 1) dan kontrol negatif (stadium skizon) (line 6), kontrol negatif (stadium cincin) (line 7). Kultur parasit malaria (line 2) dan hemoglobin standar (Sigma) (line 8). Globin akan muncul pada posisi \pm 11 kDa (line 1). 


\section{KESIMPULAN}

Berdasarkan pengujian yang dilakukan dapat disimpulkan bahwa mekanisme aksi $\alpha$-mangostin dari G. tetranda menyebabkan penundaan perkembangan dari stadium trofozoit menjadi stadium skizon sehinga pada jam ke 48 menyebabkan kematian parasit. $\alpha$ mangostin juga menyebabkan akumulasi globin di dalam vakuola makanan parasit malaria $P$. falciparum.

\section{UCAPAN TERIMA KASIH}

Terima kasih kepada Fakultas Farmasi Universitas Airlangga, ITD Unair, FMIPA UB, Eijkman Institute, Jakarta. Dirjen Dikti sebagai sponsor dalam penelitian fundamental (2007) dan HPTP (2008 dan 2009). UP. Fakultas Farmasi Universitas Mulawarman.

\section{DAFTAR PUSTAKA}

1. Mahabusarakam, W.; Kuaha, K.; Wialirat, W.; \& Taylor, W.C. 2006, Prenylated Xanthones as Potential Antiplasmodial Substances, Planta Med 2006; 72; 912-916

2. Ersam, T.; Santosa, M.; \& Widyawaruyanti, A. 2008, Kajian Bioaktivitas Dan Mekanisme Aksi Antimalaria Dari Senyawa Santon Pada Tumbuhan Wadung (Garcinia Tetranda Pierre), Laporan Akhir Penelitian HPTP, LPPM-ITS; Surabaya

3. Sherman, I.W. 1998, Malaria, Parasite Biology, Pathogenesis and Protection, American Society for Microbiology Press; Washington, D.C., USA

4. Saxena, S.; Pant, N.; Jain, D.C.; \& Bhakuni, R.S. 2003, Antimalarial Agents from Plant Sources, Review Articles, Current Science Vol. 85 No. 9, November 10, hal 1314-1326

5. Rosenthal, P.J. 2002, Hydrolysis of Erythrocyte Proteins by Proteases of Malaria Parasites, Current Opinion in Hematology Vol. 9, hal 140-145

6. Rosenthal, P.J.; Wollish, W.S.; Palmer, J.T.; \& Rasnick, D. 1991, Antimalarial Effects of Peptide Inhibitors of a Plasmodium falciparum Cysteine Proteinase, Journal Clinical Investigation Vol. 88, November, hal 14671472

7. Rosenthal, P.J 1995, Plasmodium falciparum: Effects of Proteinase Inhibitors on Globin Hydrolysis by Cultured Malaria Parasites, Experimental Parasitology Vol. 80, hal 272281 